\title{
KORELASI KETERAMPILAN MEMBACA PEMAHAMAN TEKS EKSPOSISI DENGAN KETERAMPILAN MENULIS TEKS EKSPOSISI SISWA KELAS VIII SMP NEGERI 1 ULAKAN TAPAKIS
}

\author{
Ilham Furqani', Afnita ${ }^{2}$ \\ furqaniilham2@gmail.com, afnita@fbs.unp.com \\ Universitas Negeri Padang
}

\begin{abstract}
Abstrak - Artikel ini bertujuan untuk (1) menjelaskan tingkat keterampilan membaca pemahaman teks eksposisi siswa kelas VIII SMP Negeri 1 Ulakan Tapakis, (2) untuk menggambarkan tingkat keterampilan menulis teks eksposisi siswa kelas VIII SMP Negeri 1 Ulakan Tapakis; dan (3) mendeskripsikan keterakaitan keterampilan membaca pemahaman teks eksposisi dengan keterampilan menulis teks eksposisi siswa kelas VIII SMP Negeri 1 Ulakan Tapakis. Jenis penelitian ini adalah penelitian kuantitaif dengan menggunakan metode deskriptif. Penelitian ini menggunakan tes sebagai instrumenya, yaitu tes objektif keterampilan membaca pemahaman dan tes unjuk kerja untuk keterampilan menulis teks eksposisi siswa kelas VIII SMP Negeri 1 Ulakan Tapakis. Data dalam penelitian ini yaitu skor keterampilan membaca pemahaman dan skor keterampilan menulis teks eksposisi siswa kelas VIII SMP Negeri 1 Ulakan Tapakis. Populasi dalam penelitian ini adalah siswa kelas VIII SMP Negeri 1 Ulakan Tapakis yang tedaftar pada tahun akademik 2019/2020 yang berjumlah 168 orang. Sampel penelitian ini berjumlah 40 orang. Pengambilan sampel penelitian ini dilakuakn dengan teknik propotional random sampling. Hasil dan pembahasan artikel ini yaitu siswa masih kesulitan dalam menulis teks eksposisi terutama dalam pemilihan diksi yang tepat. Siswa kesulitan dalam menuangkan fakta-fakta dalam tulisan. Dalam membaca pemahaman siswa masih kesulitan dalam menentukan isi yang terdapat dalam bacaan. Katerampilan menulis memberikan sumbangan yang sangat signifikan terhadap keterampilan membaca. Oleh karena itu, keterampilan membaca pemahaman teks eksposisi terhadap keterampilan menulis menulis teks eksposisi siswa kelas VIII SMP Negeri 1 Ulakan Tapakis memberikan koresional atau hubungan terhadap teks eksposisi tersebut.
\end{abstract}

Kata kunci : Korelasi, Keterampilan Membaca Pemahaman, Keterampilan Menulis, Teks Eksposisi.

\begin{abstract}
This article aims to (1) explain the level of reading comprehension skills of class VIII students of SMP Negeri 1 Ulakan Tapakis, (2) to describe the skill level of writing the exposition text of class VIII students of SMP Negeri 1 Ulakan Tapakis; and (3) to describe the relationship between reading comprehension text skill and exposition text writing skill for class VIII students of SMP Negeri 1 Ulakan Tapakis. This type of research is a quantitative study using descriptive methods. This study used a test as an instrument, namely an objective test of reading comprehension skills and a performance test for the writing skills of an exposition text of class VIII students of SMP Negeri 1 Ulakan Tapakis. The data in this study were the scores of reading comprehension skills and the scores of students' exposition text writing skills in grade VIII SMP Negeri 1 Ulakan Tapakis. The population in this study were 168 grade students of SMP Negeri 1 Ulakan Tapakis registered in the academic year 2019/2020. The research sample consisted of 40 people. The research sample was taken by using proportional random sampling technique. The results and discussion of this article show that students still have difficulty writing exposition texts, especially in choosing the right diction. Students have difficulty putting facts in writing. In reading, students' understanding still has difficulty in determining the content contained in the reading. Writing skills provide a very significant contribution to reading skills. Therefore, the reading skills of the exposition text understanding on the writing skills of the class VIII students of SMP Negeri 1 Ulakan Tapakis provide a correlation or relationship to the exposition text.
\end{abstract}

Keywords: Correlation, Reading Comprehension Skills, Writing Skills, Exposition Texts. 


\section{PENDAHULUAN}

Aspek berbahasa dalam kurikulum 2013 mencakup enam aspek, yaitu menyimak, berbicara, membaca, menulis, menyaji dan memirsa. Keenam keterampilan tersebut sangat penting dan saling berhubungan satu sama lainya. Diantara keenam keterampilan tersebut, menulis dianggap sebagai komponen yang sangat penting. Hal ini dianggap penting karena dengan menulis seseorang dapat mengungkapkan pikiran dan gagasan ke dalam bentuk tulisan untuk mencapai tujuan tertentu.

Penguasaan keterampilan menulis sebagai keterampilan berbahasa yang bersifat produkif, tidaklah bisa dicapai dengan hasil maksimal jika penguasaan keterampilan berbahasa bersifat reseptif, yaitu membaca dan menyimak tidak dikuasai dengan baik. Hal ini bisa dilihat dari kenyataan sehari-hari, seseorang akan bisa berbicara dengan baik jika pokok permasalahan yang akan dibicarakan itu dipahaminya dengan baik. Demikian juga halnya untuk menulis, seseorang akan dapat menulis dengan baik jika apa yang akan ditulisnya itu juga dipahaminnya dengan baik. Pemahaman terhadap bahan yang akan dibicarakan atau ditulis semuanya bersumber dari hasil simakan atau bacaan yang sudah pernah disimak atau dibaca.

Keterampilan menulis sangat dibutuhkan untuk menyampaikan pesan, ide atau gagasan dalam bentuk komunikasi langsung atau tidak secara tatap muka. Pada kegiatan menulis, penulis harus terampil dalam menuangkan ide pokok agar pembaca dapat mengerti pesan yang disampaikan lewat tulisan. Untuk itu, penulis harus melakukan banyak latihan agar memiliki keterampilan menulis yang baik. Selain itu, keterampilan menulis juga menuntut siswa untuk mempunyai pengetahuan yang luas, misalnya kaidah-kaidah dalam menulis, menguasai kosakata dan sebagainya.

Menurut Gani (dalam Putri dkk, 2019:189), keterampian menulis adalah sebagai proses melambangkan bunyi-bunyi ujaran berdasarkan aturan-aturan tertentu. Artinya segala ide, pikiran dan gagasan yang ada pada penulis disampaikan dengan cara menggunakan lambanglambang bahasa yang berpola. Sementara itu Tarigan (2008:12) mengemukakan bahwa keterampilan menulis adalah salah satu keterampilan berbahasa yang produktif dan ekspresif yang digunakan untuk berkomunikasi secara tidak langsung dan tidak secara tatap muka dengan pihak lain.

Salah satu keterampilan yang harus dikuasai oleh siswa pada pembelajaran bahasa Indonesia adalah menulis teks eksposisi. Keterampilan menulis teks eskposisi merupakan salah satu keterampilan menulis yang berfungsi untuk menyampaikan gagasan dan pemikiran tentang suatu permasalahan berdasarkan argumentasi yang kuat. Menulis teks eksposisi dalam kurikulum 2013 tercantum pada kompetensi inti (KI) ke-4, yaitu "Mencoba, mengolah, dan menyaji dalam ranah konkret (menggunakan, mengurai, merangkai, memodifikasi dan membuat) sesuai dengan yang dipelajari di sekolah dan sumber lain yang sama dalam sudut pandang atau teori".

Berdasarkan kurikulum 2013, teks eksposisi adalah jenis teks yang berfungsi untuk 
mengungkapkan gagasan atau mengusulkan sesuatu berdasarkan argumentasi yang kuat. Kosasih (2013:122) berpendapat bahwa fungsi teks eksposisi adalah memaparkan sejumlah pengetahuan. Menurut Prasitio dkk (2017:395) teks eksposisi berbeda dengan teks diskusi yang berisi dua argumentasi, teks eksposis hanya berisi satu sisi argumentasi yaitu sisi yang mendukung atau sisi yang menolak.

Kenyataan dilapangan menunjukan bahwa dalam menulis teks eksposisi, siswa masih mengalami kesulitan. Hal itu dibuktikan dengan penelitian yang dilakukan oleh beberapa peneliti di Indonesia yakni, Lidya Vega (2014), Rezki Satria(2014), Maya Sri Mangalandong (2017), Novia (2017) dan Eni Fatma Wulandari (2018). Kelima peneliti tersebut menyatakan bahwa keterampilan menulis teks eksposisi masih banyak mengalami kesulitan.

Permasalahan yang dialami siswa terkait dengan keterampilan membaca pemahaman teks eksposisi terhadap keterampilan menulis teks eksposisi, yaitu. Pertama, siswa kurang mampu menulis teks eksposisi dengan struktur yang sempurna. Hal ini disebabkan siswa belum memahami masing-masing pengertian dari struktur teks eksposisi tersebut, sehingga tulisan yang dihasilkan masih belum sesuai dengan struktur penulisan teks eksposisi yang seharusnya. Kedua, siswa kurang mampu mengembangkan ide atau permasalahan yang menjadi topik pembahasan dalam teks tersebut. Sehingga teks eksposisi yang ditulis masih kurang penjelasan dan pemaparanya. Ketiga, siswa kurang mampu mengembangkan

diksi. Masih terdapat penggunaan kata yang kurang tepat dalam tulisan tersebut.

Keterampilan menulis erat kaitannya dengan keterampilan membaca. Keahlian dalam menulis tidak mungkin terlaksana jika tidak disertai dengan kebiasaan membaca. Membaca adalah sarana utama menuju keterampilan menulis. Membaca dan menulis merupakan dua keterampilan berbahasa yang saling melengkapi. Penulis yang baik tentunya tercipta dari pembaca yang baik pula. Agar siswa tidak kesulitan dalam menuangkan serta mengembangkan ide dan gagasanya, diperlukan pengetahuan yang didapat dari kegiatan membaca.

Salah satu keterampilan membaca yang dipelajari di sekolah yaitu keterampilan membaca pemahaman. Keterampilan membaca pemahaman merupakan salah satu kegiatan membaca yang bertujuan untuk memahami isi yang terdapat di dalam bacaan. Agustina (2008:15) mengemukakan bahwa membaca pemahaman adalah membaca yang dilakukan tanpa mengeluarkan bunyi atau suara. Dalam membaca jenis ini tidak dituntut pembacanya untuk membunyikan atau mengoralkan bacaanya, tetapi hanya menggunakan mata untuk melihat dan hati serta pikiran untuk memahaminya. Menurut Khasanah dan Cahyani (2016:162) membaca pemahaman lebih menekankan pada penguasaan isi bacaan, bukan pada indah, cepat, atau lambatnya membaca.

Pembelajaran bahasa Indonesia,
khususnya dalam pembelajaran membaca
pemahaman banyak hal dan faktor yang
mempengaruhi keberhasilan belajar siswa, antara
lain, ketekunan dan kerajinan siswa dalam


mengikuti proses KBM. Menurut Adawiyah (2003) membaca pemahaman mampu meningkatkan hasil belajar siswa. Tidak hanya meningkatkan hasil belajar, membaca pemahaman juga membuat siswa mampu menjelaskan maksud, tujuan dan makna bacaan, menentukan pokok pikiran dan menyimpulkan isi bacaan dengan baik. Keterampilan membaca pemahaman perlu dikuasai agar siswa mampu menulis teks eksposisi dengan baik. Kegiatan membaca pemahaman perlu dikuasai agar siswa mampu menulis teks eksposisi dengan baik. Kegiatan membaca pemahaman dilakukan agar siswa mampu memahami sebuag teks. Hal ini sesuai dengan kompetensi initi (KI) ke3, yaitu "Memahami pengetahuan (faktual, konseptual, dan prosedural) berdasarkan rasa ingin tahunya tentang ilmu pengetahuan, teknologi, seni budaya terkait fenomena dan kejadian tampak mata.

Tarigan (2008:16) menyatakan bahwa antara menulis dan membaca mempunyai hubungan yang sangat erat. Apabila seseorang menuliskan sesuatu, pada prinsipnya ingin agar tulisan itu dibaca oleh orang lain, paling sedikit dapat dibaca diri sendiri. Hal ini dituntut adanya keterampilan membaca pemahaman seseorang agar mempermudah dalam menulis teks eksposisi.

Keterampilan menulis teks eksposisi, salah satu faktor yang mempengaruhinya adalah keterampilan membaca, khususnya membaca pemahaman. Keduanya saling berhubungan yaitu sama-sama membutuhkan proses berpikir dan memahami sebuah bacaan. Dari hasil bacaan tersebut siswa mampu menulis teks eksposisi karena telah memahami isi bacaanya. Sebaliknya, siswa yang tidak memiliki kemampuan membaca yang baik akan sulit memahami tulisan yang dibacanya.

Keterampilan membaca siswa kelas VIII di SMP Negeri 1 Ulakan Tapakis tergolong masih di bawah standar, khususnya untuk teks eksposisi. $\mathrm{Hal}$ tersebut disebabkan oleh beberapa permasalahan sebagai berikut. Pertama, kegiatan membaca membuat siswa menjadi mengantuk karena siswa terbiasa diberi bacaan yang cukup panjang dengan bahasa yang sulit. Kedua, siswa sulit memahami bacaan yang dibacanya dengan baik sehingga juga kesulitan memahmi fungsi struktur, dan ciri kebahasaan teks eksposisi.

Berdasarkan permasalahan yang dikemukakan di atas, dapat disimpulkan bahwa keterampilan membaca pemahaman dan keterampilan menulis teks eksposisi siswa masih rendah. Keterampilan membaca pemahaman dan keterampilan menulis teks eksposisi tersebut harus dilatihkan agar ditemukan relavansi dan hubungan positif yang signifikan diantara keduanya. Oleh karena itu, penelitian mengenai korelasi keterampilan membaca pemahaman dengan katerampilan menulis teks eksposisi siswa kelas VIII SMP Negri 1 Ulakan Tapakis penting dilakukan.

Sehubungan dengan hal di atas, penelitian ini bertujuan untuk mendeskripsikan hal sebagai berikut. Pertama, mendeskripsipkan keterampilan membaca pemahaman siswa kelas VIII SMP Negeri 1 Ulakan Tapakis. Kedua, mendeskripsipkan keterampilan menulis teks eksposisi siswa kelas VIII SMP Negeri 1 Ulakan Tapakis. Ketiga, menganalisis korelasi keterampilan membaca pemahaman dengan keterampilan menulis teks 
eksposisi siswa kelas VIII SMP Negeri 1 Ulakan Tapakis.

\section{METODE PENELITIAN}

Jenis penelitian ini adalah penelitian kuantitatif. Digolongkan penelitian kuantitatif karena data dari penelitian ini berupa angka, yaitu skor tes keterampilan membaca pemahaman teks eksposisi dan skor keterampilan menulis teks eksposisi. Skor tersebut diperoleh dari tes yang diberikan kepada siswa, lalu skor tersebut dianalisis dengan menggunakan rumus statistik.

Metode yang digunakan dalam penelitian ini adalah metode deskriptif. Dikatakan metode deskriptif karena penelitian ini mendeskripsikan, menganalisis dan menginterpretasikan data-data berupa angka dan variabel yang diteliti. Selanjutnya, menemukan ada tidaknya hubungan antara variabel yang satu dengan variabel lainya. Dalam hal ini hubungan membaca pemahaman teks eksposisi dengan keterampilan menulis eksposisi.

Penelitian ini menggunakan tes sebagai instrumenya, yaitu tes objektif keterampilan membaca pemahaman dan tes unjuk kerja untuk keterampilan menulis teks eksposisi siswa kelas VIII SMP Negeri 1 Ulakan Tapakis. Berdasarkan tes yang diberikan kepada siswa diperoleh data penelitian berupa angka, yaitu skor keterampilan membaca pemahaman dan skor keterampilan menulis teks eksposisi.

Pupulasi penelitian adalah seluruh siwa kelas kelas VIII SMP Negeri 1 Ulakan Tapakis yang terdaftar pada tahun ajaran 2019/2020 yang berjumlah 168 orang siswa yang tersebar dalam 5 kelas. teknik pengambilan sampel yang digunakan adalah preportional random sampling yaitu sampel yang terdiri dari sub-sub sampel yang diambil secara acak, berdasarkan proporsi jumlah siswa per kelas. Teknik yang digunakan dalam pengambilan sampel dilakukan dengan teknik undian atau cabut lot. Persentase sampel yang diambil dalam penelitian ini adalah $25 \%$ dari populasi siswa kelas VIII SMP Negeri 1 Ulakan Tapakis. Denbgan demikian, sampel yang diambil dalam penelitian nini adalah 42 orang siswa.

Dalam penelitian ini terdapat dua variabel. Pertama, keterampilan membaca pemahaman siswa kelas VIII SMP Negeri 1 Ulakan Tapakis sebagai variabel bebas $(\mathrm{x})$. Kedua, keterampilan menulis teks eksposisi siswa kelas VIII SMP Negeri 1 Ulakan Tapakis sebagai variabel terikat (variabel Y). Data dalam penelitian ini adalah skor hasil tes keterampilan membaca pemahaman berupa tes objektif dan skor hasil tes keterampilan menulis teks eksposisi berupa tes unjuk kerja.

\section{PEMBAHASAN}

\section{Keterampilan Menulis Teks Eksposisi Siswa Kelas VIII SMP Negeri 1 Ulakan Tapakis}

Penilaian keterampilan menulis teks eksposisi siswa kelas VIII SMP Negeri 1 Ulakan Tapakis terdiri atas tiga indikator dengan rata-rata hitung 79,17 dengan kualifikasi baik. Dari tiga indikator yang dinilai tersebut, indikator tertinggi dikuasai siswa adalah indikator struktur teks eksposisi. Berdasarkan perolehan nilai 
keterampilan menulis teks eksposisi indikator struktur teks diperoleh rata-rata hitung $(97,50)$ dan berada pada kualifikasi sempurna. Bertolak dari nilai rata-rata tersebut, disimpulkan bahwa sebagian besar siswa sudah mampu memahami struktur teks eksposisi dalam tulisan.

Kesalahan paling banyak yang dilakukan siswa terdapat pada indikator penggunaan diksi dengan nilai rata-rata 51,67 . Berdasarkan kriteria penilaian yang dilakukan pada tulisan siswa terlihat bahwa siswa masih kurang mampu memberikan penjelasan terhadap ide yang ingin disampaikanya sehingga pembaca merasa yakin dengan apa yang disampai penulis. Sementara itu, untuk indikator isi teks eksposisi dengan nilai rata-rata $(88,33)$ dan berada pada kualifikasi baik sekali.

Berdasarkan dari hasil penilaian tulisan teks eksposisi siswa, dapat disimpulkan bahwa katerampilan menulis eksposisi siswa khsususnya untuk indikator penggunaan diksi sebagai alat untuk memberikan keyakinan kepada pembaca bahwa topik yang ditulis adalah topik yang penting untuk dibahas tidak tercapai. Dalam tulisanya siswa kesulitan dalam menuangkan fakta-fakta dalam tulisan. Pada tulisan siswa terlihat bahwa penulis tidak mampu menggunakan kebahasaan yang baik dan benar. Penulis hanya memberikan pernyataan yang sangat umum dan ini membuktikan bahwa pada dasarnya penulis tidak memahami apa yang seharusnya diungkapkanya dalam tulisan tersebut.

Ketidakberhasilan ini dapat disebabkan lemahnya tesis atau pernyataan sebagai struktur awal tulisan. Selain itu, ketidakberhasilan siswa meyakinkan pembaca juga dipengaruhi oleh penggunaan afiks, penggunaan pronomina, penggunaan frasa yang tidak sesuai dengan bahasa yang benar. Pemberian fakta dan contoh untuk memperkuat isi yang masih kurang jelas. Kekurangan yang ditemukan pada bagian struktur sangat berpengaruh terhadap pencapaian isi teks yang dikemukakan masih belum jelas dan kadang tidak relevan dengan ide utama.

Kejelasan penggunaan diksi dalam sebuah teks eksposisi dapat dikatakan sebagai hal pertama yang harus diuraikan secara jelas. Hal ini disebabkan karena bagian pembuka ini merupakan bagian penentu untuk kejelasan isi dan ketercapaian tujuan penulisan. Karena ketidakjelasan ide pada bagian pendahuluan, maka dapat dipastikan pada bagian berikutnya yaitu tubuh (body) yang terdiri dari beberapa paragraf, yang memamparkan argumen-argumen dalam bentuk penjelasan dengan contoh, fakta, bertujuan untuk mendukung dan mengembangkan isi yang menyajikan unsur kebahasaan tentang keadaan, peristiwa tempat atau benda juga tidak akan dapat diuraikan dengan baik. Dengan kata lain, isi merupakan bagian pengontrol pada eksposisi sehingga ide penulis dapat disampaikan secara teroganisir dan tidak bertele-tele. Jadi, agar isi teks eksposisi dapat memberikan informasi tentang suatu objek, maka penulis harus mampu memberikan sebuah ide yang dapat diinterpretasikan dengan baik dan diperkuat dengan fakta-fakta yang ada.

\section{Keterampilan Membaca Pemahaman Siswa} Kelas VIII SMP Negeri 1 Ulakan Tapakis

Berdasarkan hasil penelitian dan hasil analisis data, diketahui bahwa keterampilan membaca pemahaman teks eksposisi siswa kelas 
VIII SMP Negeri 1 Ulakan Tapakis diklasifikasikan menjadi tiga kategori, yaitu sempurna, lebih dari cukup dan kurang. Nilai rata-rata keterampilan membaca pemahaman teks eksposisi siswa kelas VIII SMP Negeri 1 Ulakan Tapakis adalah 82,56 dengan tingkat pengusaan berada pada kualifikasi baik pada skala 10 .

Indikator yang paling dikuasai adalah indikator menentukan struktur teks eksposisi dengan nilai rata-rata 84,12 dengan tingkat penguasaan berada pada kualifikasi baik. Berdasarkan dari nilai rata-rata yang diperoleh dapat dikatakan sebagian besar siswa sudah mulai mampu memahami struktur yang tercermin dari teks eksposisi yang dibacanya. Hal ini terlihat dari nilai yang diperoleh siswa dengan rata-rata berada pada kualifikasi baik.

Indikator yang kurang dikuasai siswa adalah indikator menentukan isi teks eksposisi. Nilai rata-rata siswa adalah 80,75 dengan tingkat penguasaan berada pada kualifikasi lebih dari cukup. Berdasarkan dari nilai rata-rata tersebut dapat dikatakan bahwa siswa masih mengalami kesulitan untuk menentukan isi yang terdapat dalam bacaan. Hal ini terlihat dari nilai yang diperoleh siswa dengan rata-rata berada pada kualifikasi baik.

Berdasarkan pembahasan tersebut, dapat disimpulkan bahwa nilai keterampilan membaca pemahaman teks eksposisi siswa kelas VIII SMP Negeri 1 Ulakan Tapakis masih berada pada kualifikasi baik. Oleh sebab itu, keterampilan membaca pemahaman perlu ditingkatkan lagi. Hal tersebut sejalan dengan pendapat Agustina (2008:15) yang mengemukakan bahwa tujuan membaca pemahaman adalah untuk menangkap isi atau makna dari gagasan-gagasan yang terdapat dalam bacaan.

\section{Korelasi Keterampilan Membaca Pemahaman Teks Eksposisi dengan Keterampilan Menulis Teks Eksposisi Siswa Kelas VIII SMP Negeri 1 Ulakan Tapakis}

Berdasarkan hasil deskripsi dan analisis data, ditemukan adanya korelasi antara keterampilan membaca pemahaman teks eksposisi dengan keterampilan menulis teks eksposisi siswa kelas VIII SMP Negeri 1 Ulakan Tapakis. Hal ini didukung oleh fakta hasil penelitian bahwa keterampilan membaca pemahaman teks eksposisi siswa berada pada kualifikasi baik $(82,56)$, sedangkan keterampilan menulis teks eksposisi siswa berada pada kualifikasi baik (76-85) dari keseluruhan indikator. Hal itu sesuai dengan pendapat Tarigan (dalam Mangalandong dkk, 2018:148) bahwa antara menulis dan membaca terdapat hubungan yang sangat erat. Bila seseorang menuliskan sesuatu, pada prinsipnya ia ingin agar tulisan itu dibaca oleh orang lain paling sedikit dapat kita baca sendiri pada saatlain.

Salah satu faktor yang menentukan keterampilan menulis teks eksposisi adalah kemampuan membaca, khususnya membaca pemahaman. Dari hasil bacaan tersebut, seseorang mampu menulis teks eksposisi karena telah memahami isi bacaan. Sebaliknya siswa yang tidak memiliki kemampuan membaca yang baik akan sulit memahami tulisan yang dibacanya. Bertolak dari hasil temuan tersebut dapat diketahui bahwa keterampilan membaca terbukti memberikan sumbangan yang sangat signifikan terhadap keterampilan menulis. Untuk itu, jika ingin 
meningkatkan keterampilan menulis, terlebih dahulu keterampilan membaca harus ditingkatkan.

Berdasarkan perbedaan nilai rata-rata menulis teks eksposisi dengan membaca pemahaman teks terlihat bahwa hasil belajar siswa kelas VIII SMP Negeri 1 Ulakan Tapakis cukup baik. Oleh karena itu, dapat disimpulkan bahwa keterampilan membaca pemahaman teks eksposisi terhadap keterampilan menulis teks eksposisi siswa kelas VIII SMP Negeri 1 Ulakan Tapakis memberikan korelasional atau hubungan terhadap teks eksposisi tersebut.

\section{SIMPULAN}

Berdasarkan hasil penelitian, disimpulkan tiga hal berikut. Pertama, keterampilan menulis teks eksposisi siswa kelas VIII SMP Negeri 1 Ulakan Tapakis berada pada kualifikasi baik. Hal ini terlihat dari perolehan rata-rata hitung tes menulis teks eksposisi sebesar 79,17. Kedua, keterampilan membaca pemahaman teks eksposisi siswa kelas VIII SMP Negeri 1 Ulakan Tapakis berada pada kualifikasi baik. Hal ini disimpulkan berdasarkan rata-rata hitung sebesar 82,56 . Ketiga, terdapat hubungan yang signifikan antara keterampilan membaca pemahaman teks eksposisi dan keterampilan menulis teks eksposis siswa kelas VIII SMP Negeri 1 Ulakan Tapakis. Berdasarkan pengujian tersebut, dapat disimpulkan bahwa siswa yang memperoleh nilai keterampilan menulis teks eksposisi tinggi, juga memperoleh nilai keterampilan membaca teks eksposisi yang tinggi. Sebaliknya, jika siswa memperoleh nilai keterampilan menulis teks eksposisi rendah, juga memperoleh nilai keterampilan membaca teks eksposisi rendah.

\section{Daftar Rujukan}

Adawiyah, Rabiatul. 2013. "Peningkatan Kemampuan Membaca Pemahaman Melalui Metode Diskusi Siswa Kelas IV SDN Inti Tomoti". Jurnal Kreatif Tadulako. Online Vol 5 No 3. https://media.neliti.com/media/publicati ons/114314-ID-peningkatankemampuan-membacapemahaman.pdf. Diunduh 12 Februari 2020.

Agustina. 2008. Pembelajaran Keterampilan Membaca (Buku Ajar). Padang: Jurusan Bahasa dan Sastra Indonesia FBS UNP.

Kosasih, E. (2014) Strategi Belajar dan Pembelajaran Implementasi Kurikulum 2013. Bandung: Yrama Widya

Khasanah dan Cahyani. 2016. "Peningkatan Kemampuan Membaca Pemahaman dengan Strategi Question Answer Relationships (Qar) Pada Siswa Kelas V Sekolah Dasar. Jurnal pedagogik Pendidikan Dasar". Online Vol 4, No 2, 161-175.

https://ejournal.upi.edu/index.php/ppd/a rticle/view/6468. Diunduh 10 Februari 2020.

Mangalandong, Maya Sry, dkk. 2018. "Korelasi Keterampilan Membaca Pemahaman Teks Eksposisi dengan Keterampilan Menulis Teks Eksposisi Siswa Kelas X 
SMK Negeri 9 Padang". Juranal

Pendidikan Bahasa dan Sastra Indonesia. Online Vol 7 No 3 144-149. http://ejournal.unp.ac.id/index.php/pbs/ article/view/100724. Diunduh 10 Februari 2020.

Prastio, Toto, dkk. (2017). "Korelasi Keterampilan Memahami Teks Eksposisi dengan Keterampilan Menulis Teks Eksposisi Siswa Kelas X SMA Negeri 1 Painan". Jurnal Pendidikan Bahasa dan Sastra Indonesia. 6(2), 388-394. http://ejournal.unp.ac.id/. Diunduh pada 10 Februari 2020.

Putri, Sri Rani, dkk. 2019. "Korelasi Keterampilan
Membaca Pemahaman Teks
Eksplanasi dengan Keterampilan Menulis Teks Eksplanasi Siswa Kelas
VIII SMP Negeri 2 Batusangkar". Jurnal Pendidikan Bahasa dan Sastra Indonesia. Online Vol. 8 No.8, 188-194. http://ejournal.unp.ac.id/index.php/pbs/ article/view/103935. Diunduh 12 Februari 2020.

Tarigan, Henry Guntur. 2008. Menulis sebagai suatu keterampilan berbahasa. Bandung: Angkasa 